\title{
MAKNA TOPONIM DI TANGERANG SEBAGAI REPRESENTASI KEBERADAAN ETNIS CINA BENTENG: SEBUAH KAJIAN LINGUISTIK HISTORIS KOMPARATIF
}

The Meaning of Toponym in Tangerang as Representation of Cina Benteng Existence: A Study of Comparative Historical Linguistics

\author{
Sonya Ayu Kumala \\ Multamia. RMT Lauder \\ Universitas Indonesia \\ Jl. Margonda Raya, Kecamatan Beji, Kota Depok, Jawa Barat, Indonesia \\ sonyaa.ayuu@gmail.com
}

Naskah Diterima Tanggal 10 Februari 2021—Direvisi Akhir Tanggal 22 September 2021—Disetujui Tanggal 7 Desember 2021 doi: https://doi.org/10.26499/rnh.v10i2.4048

\begin{abstract}
Abstrak
Etnis Tionghoa di Tangerang yang disebut sebagai Cina Benteng, yaitu pribuminya Tangerang. Sebutan Benteng terkait erat dengan sejarah awal migrasi Cina Benteng di Tangerang yaitu mendiami bentengbenteng dan bercocok tanam sebagai petani atau nelayan. Berkulit coklat, bermata sipit, dan memelihara meja abu, merupakan sekilas potret Cina Benteng. Sehubungan dengan fenomena tersebut di atas, pada penelitian ini penulis bertujuan menelaah makna toponim di Tangerang untuk dikaitkan dengan keberadaan atau eksistensi dari etnis Cina Benteng. Penelitian ini menggunakan ancangan linguistik historis komparatif yang memanfaatkan nama sebagai satuan linguistik yang akan ditelisik makna, dan kaitannya dengan aspek historis. Teori yang digunakan dalam penelitian ini adalah teori makna etimologi, teori makna semiotik Barthes dan, dan Nystorm (2016). Toponim atau nama tempat adalah salah satu cabang kajian dari onomastika (Rais et al, 2008). Onomastika mengkaji nama diri dan nama tempat. Nama hadir tidak semata untuk memenuhi fungsi identifikasi akan tetapi kehadiran nama juga mengungkap aspek sosial budaya yang ada. Sebuah nama dikonstruksikan, dimaknai, digunakan secara terus menerus atau bahkan kemudian diganti dan ditinggalkan. Kajian nama tempat atau toponim merupakan bentuk kajian linguistik historis komparatif yang memanfaatkan cabang kajian linguistik seperti semantik dan sosiolinguistik serta bidang lain diluar linguistik yang bersinggungan (Lauder, 2015). Data untuk tulisan ini dikumpulkan dari dokumentasi tertulis atau peta. Selain itu penulis juga memanfaatkan metode etnografi untuk dapat melihat kaitan sebuah nama tempat dengan masyarakat sekitar. Hasil penelitian ini menunjukan makna toponim di Tangerang, terkait erat dengan keberadaan Cina Benteng baik di masa lampau hingga dewasa ini.
\end{abstract}

Kata-kata Kunci: makna toponim, linguistik historis komparatif, Cina benteng

\begin{abstract}
Cina Benteng in Tangerang called as Cina Benteng, the native of Tangerang. The name Benteng is closely related to the early history of Chinese migration. Cina Benteng in Tangerang, namely living in forts and growing crops as farmers or fishermen. Brown skin, slanted eyes, and keep an ash table, is a glimpse of the portrait of Cina Benteng. Regarding to that phenomena mentioned above, in this study the author examines the meaning of toponyms in Tangerang to be associated with the existence Cina Benteng. This study uses a comparative historical linguistic approach that uses names as linguistic units to examine meaning, and its relation to historical context. The theory used in this study is etymological theory, semiotic's theory meaning by Barthes and, and Nystorm (2016). Toponyms or place names are one of the branches of onomastics (Rais et al, 2008). Onomastics examines self names and place names. The name is present not only to fulfill the function of identification, but the presence
\end{abstract}


of the name also reveals the existing socio-cultural aspects. A name is constructed, interpreted, used continuously or even later replaced and abandoned. The study of place names or toponyms is a form of comparative historical linguistic study that utilizes branches of linguistic studies such as semantics and sociolinguistics as well as other fields outside of intersecting linguistics (Lauder, 2015). The data for this paper were collected from written documentation or maps. In addition, the author also uses ethnographic methods to be able to see the relationship of a place name with the surrounding community. The result of the study shows the meaning of toponym in Tangerang are strongly related to the existence of Cina Benteng from the old times until modern times.

Keywords: meaning of toponym, comparative historical linguistics, Cina Benteng

How to Cite: Kumala, Sonya Ayu dan Multamia. RMT Lauder (2021). Makna Toponim di Tangerang sebagai Representasi Keberadaan Etnis Cina Benteng: Sebuah Kajian Linguistik Historis Komparatif. Ranah: Jurnal Kajian Bahasa. 10(2). 304-313. doi: https://doi.org/10.26499/rnh.v10i2.4048

\section{PENDAHULUAN}

Riset linguistik historis komparatif ini mengangkat isu toponimi dalam kaitannya dengan representasi eksistensi atau keberadaan etnis Cina Benteng di Tangerang, Banten. Pertanyaan penelitian yang berusaha dijawab dalam penelitian ini adalah bagaimana makna toponim di Tangerang terkait dengan keberadaan Cina Benteng? Melalui pertanyaan penelitian tersebut penelitian ini berusaha mengisi gap penelitian terdahulu yaitu telaah makna dalam kajian linguistik yang merepresentasikan eksistensi sebuah etnis budaya. Hal ini sebagaimana sudah dikaji di penelitian-penelitian terdahulu kajian makna dengan objek Cina Benteng baru menyasar tingkatan makna dalam bahasa, belum berinteraksi dengan aspek sosial budaya lain yang menjadi latar. Toponimi sebagai bentuk nama, dipahami sebagai bentuk linguistic evidence yang ditelisik pada tingkatan makna. Lebih jauh lagi, aspek sejarah dan budaya memegang peranan penting tentang makna toponimi sebuah wilayah atau lokasi. Makna toponimi apabila dibawa dalam konteks sosial terkait erat dengan isu eksistensi, representasi dan identitas sebuah etnis budaya, secara khusus dalam riset ini adalah Cina Benteng.

Berkulit coklat, bermata sipit, dan memelihara meja abu di rumahnya. Itulah mereka, etnis Cina Benteng di Tangerang Banten atau biasa disingkat ciben. Meskipun etnis Cina kulit mereka cenderung coklat atau hitam karena turun temurun dikenal dengan mata pencaharian sebagai petani. Hal inilah yang menyebabkan mereka diberi julukan hitachi, hitam tapi cina. Cina Benteng dikenal sebagai pribuminya Tangerang, selain karena ciri fisiknya yang hampir serupa dengan pribumi, hal ini juga dikarenakan keberadaan mereka yang diperkirakan datang sebelum kedatangan Belanda di Batavia, yaitu sebelum abad 17. Berdasarkan catatan sejarah, Cina Benteng diperkirakan bagian dari ekspedisi Laksamana Cheng Ho. Laksamana Cheng Ho singgah terlebih dahulu di Banten dan Sunda Kelapa baru kemudian singgah di kota pelabuhan lain di pesisir Jawa (Daradjadi, 2017: 46).

Di era modern ini, etnis Cina Benteng masih menjalankan budaya-budaya leluhur misalnya ritual pernikahan, peribadatan, upacara kematian, atau perayaan hari-hari tertentu dalam satu tahun. Meskipun begitu, etnis Cina Benteng sudah tidak lagi menggunakan bahasa asli mereka dalam kehidupan pergaulan sehari hari. Berdasarkan disertasi tentang pemetaan bahasa di Tangerang oleh Prof. Multamia Lauder (1990), etnis Cina Benteng mengembangkan bahasa yang menjadi ciri khas mereka yaitu Betawi Ora. Pemetaan bahasa tersebut diperbaharui oleh Badan Bahasa di tahun 2018 yang menunjukkan bahwa tidak disebutkan lagi adanya bahasa Betawi Ora, hanya bahasa Jawa, Lampung Cikoneng, dan Sunda ${ }^{1}$.

Tidak ditemukan atau tidak dicantumkan bahasa Betawi Ora ini menurut sudut pandang penulis menjadi sebuah pekerjaan rumah untuk dapat dijelaskan. Hal ini karena bahasa adalah 
salah satu aspek pembentuk kebudayaan universal (Koentjaraningrat, 1997). Lebih jauh lagi, terkait penggunaan bahasa, Gobard (1967) juga memaparkan bahwa bahasa memiliki empat fungsi yaitu vernacular (komunikasi), vehicular (administrasi), cultural reference function (fungsi referensi sosial) dan mythic religion function (fungsi religi-mistis). Sebuah bahasa meskipun dalam penggunaannya sudah tidak memenuhi fungsi vernacular yaitu sebagai alat komunikasi, bahkan ketika bahasa tersebut sama sekali tidak digunakan atau sudah mati akan tetapi bahasa tersebut dianggap masih ada dengan transformasi fungsi yang berbeda atau baru yaitu sebagai penanda identitas.

Selanjutnya, penulis akan menggunakan penjelasan tentang latar belakang Cina Benteng dan situasi kebahasaan mereka untuk membentuk argumen penelitian ini. Etnis Cina Benteng tidak lagi "dianggap" menuturkan bahasa asli mereka atau Betawi Ora. Akan tetapi bahasa mereka bertransformasi menjadi sebuah tanda identitas, salah satunya bisa dilihat dalam bentuk bahasa (linguistic evidence) toponimi. Toponimi (makna nama wilayah atau tempat) dan antroponimi (nama diri) dalam disiplin ilmu linguistik merupakan bagian dari kajian onomastika (Ayatrohaedi, 1993). Toponim atau nama wilayah tidak hanya merupakan bentuk kata akan tetapi memiliki signifikansi dalam kehidupan bermasyarakat. Nama pasti memiliki makna dan dimaknai oleh masyarakat. Makna toponim mengungkap informasi-informasi sosial, budaya, sejarah, pola migrasi, atau politik identitas.

Pada riset Toponimi Etnis Cina Benteng, data dan informasi terkait toponimi digali melalui proses narasi yang dituturkan oleh tokoh masyarakat, pelaku budaya dan seni, tetua, juru kunci makam atau vihara, dan narasumber lain yang potensial. Proses bernarasi menurut Tuan (1977) dikaitkan dengan proses konstruksi ruang berdasarkan pengalaman dan perspektif penutur. Ketika narasumber menarasikan sebuah toponim sebagai bentuk ruang 'milik atau terkait etnis mereka', penulis asumsikan ada konsep identitas yang mereka bawa dalam narasinya. Identitas oleh Hall (1990) didefinisikan sebagai sebuah produk yang tidak pernah selesai, subjek dari permainan secara terus menerus dari kekuatan politik, sosial, dan budaya. Bagaimana toponim dimaknai, dinarasikan, dan dikaitkan dengan identitas budaya menjadi argumen dari riset yang sedang dirintis oleh penulis.

Selanjutnya, makna toponim dikaji dari teori pemaknaan toponim oleh Nyström. Berpijak dari kajian makna semantik Nyström (2016: 41) menjelaskan bahwa nama memiliki makna konotasi dan denotasi. Pada tingkatan denotasi nama akan merujuk pada referennya secara langsung. Sedangkan, pada tahapan konotasi nama akan memiliki informasi, gambaran, dan kaitan yang bersifat acak atas suatu nama dan dimiliki serta dipahami baik oleh individu ataupun masyarakat. Selanjutnya, Nyström menambahkan bahwa nama sebagai bentuk kosakata memiliki kaitan dengan leksikon-leksikon yang dikaitkan atau disasar oleh pemilik atau pembentuk nama karena terkait asosiasi atau aspek emotif yang mereka miliki. Nyström memaparkan makna asosiatif sebagai bentuk ungkapan yang sifatnya personal yaitu dapat berbeda antara satu orang dengan orang yang lain, atau satu kelompok dengan kelompok yang lain. Sedangkan, emotif adalah makna yang ketika diperdengarkan membangkitkan gejolak emosi atas peristiwa, perasaan, atau ingatan tertentu.

Kajian terdahulu terkait toponim sudah cukup banyak dilakukan di Indonesia dalam berbagai disiplin ilmu. Pada displin ilmu lingustik, toponim cukup berkembang dengan baik dalam satu dekade terakhir ini baik yang mencakup nama lokasi ataupun nama diri. Pada penelitian akademik Perdana (2019) melakukan penelitian nama diri (antroponim) pada marga di batak dikaitkan dengan sejarah sosial antar marga. Sedangkan di tahun yang sama Muhatta (2019) melakukan penelitian tentang makna nama pelabuhan di sepanjang pantai utara Jawa dikaitkan dengan sejarah jalur rempah yang ada di Indonesia. Kedua penelitian di atas merupakan disertasi perdana dalam kajian linguistik yang menggunakan nama sebagai objek kajian. Mempertimbangkan dan menelaah penelitian terdahulu yang sudah ada, peneliti belum 
menemukan kerangka konseptual serupa yang mengaitkan makna nama dengan sejarah keberadaan sebuah etnis. Penelitian ini diharapkan mampu mengisi gap kaitan kajian makna nama dengan keberadaan dan sejarah etnis. Toponim sebagai wujud satuan linguistik digunakan sebagai objek pada tulisan ini.

Toponim sebagai bentuk tanda bahasa mengalami pemaknaan karena merupakan representasi ruang dan mengerucut sebagai bentuk identitas. Identitas budaya merupakan sebuah bentuk praktik sosial yang diproduksi tidak hanya dari bahasa saja tapi banyak aspek lain sebagai pembentuk. Toponimi sebagai tanda bahasa pada tingkat mikro dan dilihat sebagai bagian dari sebuah teks besar dalam tingkat makro. Pada tingkat makro ini, persilangan antara kepentingan sosial, politik, budaya, dan bahkan ekonomi terjadi. Sehingga pada tahapan ini menurut sudut pandang penulis, riset ini membutuhkan sudut pandang keilmuan lain di luar linguistik yaitu studi sejarah dan budaya. Langkah ini ditujukan agar penelitian toponimi menjawab kaitan nama dengan identitas budaya. Pemaparan di atas sekaligus menggambarkan kebutuhan riset toponimi ini untuk ditempatkan dalam konteks sosial, kultural, dan politik yang lebih luas.

Ancangan penelitian transdisiplin juga dimaksudkan agar dapat memberikan signifikansi tidak hanya pada bidang keilmuan linguistik akan tetapi juga bidang keilmuan lain dan signifikansi yang bersifat praktis. Signifikansi keilmuan untuk bidang ilmu linguistik dari riset ini ditujukan untuk mengeksplorasi makna toponimi guna mengungkap informasi terkait sejarah, budaya, dan identitas etnis. Sebagai bentuk riset transdisiplin, riset ini diharapkan dapat memberikan kebaruan dalam bidang ilmu yang terkait (di luar ilmu linguistik) dengan memberikan gambaran keberagaman penelitian yang dapat dilakukan dengan melibatkan berbagai disiplin keilmuan secara bersamaan. Selanjutnya, riset ini juga memberikan signifikansi yang bersifat praktis baik pada aspek sosial maupun politik. Pada aspek sosial penelitian ini dapat digunakan oleh pemerintah sebagai ancangan untuk City Branding, utamanya dalam industri ekonomi kreatif dan pariwisata. Eksplorasi toponimi dengan latar belakang sejarah dan budaya dapat digunakan sebagai panduan arah kebijakan dan penggalian kearifan lokal yang memiliki nilai jual ekonomis. Pada aspek politik, pengambilan kebijakan terkait nama hendaknya pemerintah atau institusi terkait bisa lebih mempertimbangkan aspek budaya dan sejarah lokal. Hal ini dikarenakan nama tidak hanya difungsikan sebagai identifikasi akan tetapi juga menyimpan memori kolektif dan bahkan identitas budaya sebuah komunitas atau etnis. Selain itu, gambaran identitas budaya yang akan didapat dari riset ini bermanfaat untuk pemerintah sebagai pijakan dalam membuat kebijakan-kebijakan utamanya yang terkait dengan hak dan kewajiban etnis minoritas di Indonesia. Hal ini sekaligus sebagai bentuk upaya perwujudan sila kelima yaitu "Keadilan sosial bagi seluruh rakyat Indonesia".

\section{LANDASAN TEORI}

Argumen dalam riset ini akan dijawab dengan memanfaatkan bagian dari linguistik historis, yaitu penelusuran etimologi yang melibatkan kamus, teori pemaknaan tanda oleh Barthes (dalam Noth, 1995) dan pemaknaan toponimi oleh Nystrom (2006) dan Hough (2016). Pada tahap rintisan riset ini, peneliti masih mengasumsikan artikulasi budaya dan eksistensi Cina Benteng dimungkinkan terjadi dalam cakupan sinkronis, atau diakronis. Hal ini dilatar belakangi dalam kurun waktu sejarah, perubahan budaya, politik tentang etnis, dan kebijakan pemerintah, membuat identitas Cina Benteng lebih tepat dilihat dari kerangka waktu masa ke masa.

Selanjutnya, argumen riset penulis juga sudah disusun dengan mempertimbangkan penelitian terdahulu yang sudah ada terkait etnis Cina Benteng, toponimi Cina Benteng, narasi Cina Benteng, dan identitas budaya Cina Benteng. Cina Benteng sudah diteliti akan tetapi hanya pada aspek tradisi lisan gambang kromong (Radjimo, 2013), upacara kematian adat Cina 
Benteng (Triyanda, 2016), upacara pernikahan adat Cina Benteng (Priscylia, 2015; Ramadhanty, 2016), pemetaan bahasa dan variasi bahasa (Lauder, 1990, Budiasih, 2015), sejarah sosial dan budaya (Budi, 2012; Zaini, 2014; Thresnawaty, 2015), dan Agama Cina Benteng (Lusiana, 2013), belum ditemukan penelitian dengan ancangan linguistik historis: toponimi terkait Cina benteng. Selanjutnya, dari sudut pandang narasi belum ditemukan penelitian terdahulu dengan sudut pandang narasi terkait Cina Benteng atau Toponimi terkait Cina Benteng. Terakhir konsep identitas, penulis menemukan penelitian oleh Sany (2013) terkait identitas Cina Benteng. Akan tetapi penelitian ini dilakukan dengan sudut pandang sosiologi dengan mengangkat kebijakan pemerintah yang berupa undang-undang kewarganegaraan terkait etnis Cina di Indonesia, khususnya Cina Benteng. Hal ini menunjukkan identitas Cina Benteng belum pernah dikaji dalam sudut pandang identitas dalam kerangka budaya dan sejarahnya. Melalui pemaparan di atas, penulis berharap riset Toponimi Wilayah Tangerang sebagai bentuk Representasi Identitas Etnis Cina Benteng dapat mengisi gap dan mengisi rumpang serta sekaligus memberikan kebaruan dalam hal penelitian linguistik historis khususnya toponimi dan identitas budaya, khususnya Cina Benteng.

Melalui uraian aspek tinjauan pustaka dan tinjauan penelitian terdahulu, riset ini diancangkan sebagai sebuah bentuk penelitian transdisiplin yaitu linguistik historis, studi budaya, sejarah, dan sosial. Pemilihan toponim sebagai bagian dari onomastika sendiri pada dasarnya sudah lintas disiplin. Seperti diketahui bersama bahwa kajian onomastik tidak hanya berdiri pada kajian linguistik, akan tetapi juga kajian geografi, teknik geodesi, dan bidang ilmu lainnya. Akan tetapi, onomastika sebagai bentuk kajian linguistik historis pada riset ini akan memaparkan makna pada cakupan leksikal, semantik, atau semiotik, yaitu ketika masyarakat memaknai nama sebagai sebuah tanda. Akan tetapi sebuah tanda bahasa dari masa ke masa mengalami perkembangan dan perubahan dalam pemaknaan.

Salah satu kajian semantik leksikal diusulkan oleh Cruse (2004) dengan asumsi dasar bahwa semantik leksikal menekankan kajiannya pada isi dari sebuah makna, alih-alih mengusulkan aspek bentuk dan gramatikal sebagai salah satu aspek yang membentuk makna. Kata-kata hadir secara mandiri sebagai sebuah tanda yang memiliki makna. Makna sebagai sebuah isi biasanya berisi ide atau gagasan yang disampaikan oleh penutur bahasa. Lebih jauh lagi, karena dianggap mewakili ide dan gagasan, makna tidak dapat dipandang sebagai sebuah satuan linguistik yang hadir dari sebuah struktur gramatikal. Lebih jauh lagi, secara spesifik, kajian tentang bentuk-bentuk leksikal dalam bahasa ini selanjutnya dikaji dalam kajian leksikologi. Leksikologi menurut Kridalaksana (20011: 142) adalah cabang dari ilmu linguistik yang mempelajari tentang leksikon-leksikon pada suatu bahasa. Leksikologi mempelajari kosakata yang ada dalam sebuah bahasa dan makna-makna yang dimilikinya dengan berbagai penjabaran konteks yang ada.

Pada penelitian toponimi kini, makna leksikal digunakan untuk mengkaji makna nama nama wilayah sebagai salah satu tanda bahasa dalam kaitannya dengan peristiwa, sejarah, dan budaya. Selain itu, penelitian toponimi ini juga mengkaji nama yang dimiliki oleh sebuah proper noun atau makna propial. Untuk mendapatkan makna leksikal dari kosakata terkait nama wilayah digunakan kamus Bahasa Indonesia dan bahasa lain yang terkait. Penelusuran makna leksikal menjadi tahapan dalam proses penemuan makna etimologi, Etimologi adalah kajian dalam linguistik yang menelusuri asal-muasal dan sejarah suatu kata. Durkin (2009) menjelaskan bahwa pada kajian etimologi bentuk dan sejarah suatu kata dapat ditelusuri, bahkan juga tahapan perkembangan sejarah suatu kata dapat ditelusuri dalam kajian etimologi. Penelusuran makna etimologi membantu untuk mendapatkan informasi tentang aspek sejarah yang juga mencakup perkembangan pemaknaan yang dilekatkan dalam suatu kata. Hal ini membuat penelisikan makna etimologis berbeda dengan makna leksikal. Pada makna leksikal, makna hadir sebagai sebuah 'isi' tanpa melihat asal-muasal dan perubahan makna dalam aspek 
sejarah, sedangkan pada makna etimologi makna dilihat sebagai sebuah entitas yang bersifat dinamis.

\section{METODE PENELITIAN}

Penelitian ini disusun dengan metode kualitatif. Data yang telah terdokumentasikan terkait Cina Benteng dan Tangerang yang berupa petadan naskah terkait akan dimanfaatkan. Penulis mendapatkan daftar nama/toponim tangerang dari Dinas Kependudukan dan Catatan Sipil. Penulis juga memanfaatkan pendekatan etnografi dalam menyelesaikan penelitian ini. Penulis melakukan wawancara dan pendekatan terhadap narasumber secara langsung. Narasumber-narasumber yang diwawancarai dalam penelitian ini sejumlah lima orang yang terdiri dari pegiat seni (1), penduduk (tetua) perwakilan dari tiap toponim (3), dan pemuka agama (2). Dari hasil wawancara tersebut kemudian penulis menangkap dalam narasi para narasumber lokasi atau wilayah selalu dikaitkan dengan kedatangan mereka, perpindahan mereka dari daerah satu ke daerah yang lain di Tangerang, peran mereka di daerah tertentu hingga kemudian dikenang sebagai nama daerah atau diberi kekuasaan untuk wilayah tersebut. Pada penelitian ini, penulis menggunakan tiga toponim yaitu Karawaci, Pasar Lama, dan Kampung Melayu. Pembatasan toponim ini dilakukan dengan mempertimbangkan keberadaan pecinan di toponim tersebut. Tiga toponim yang dipilih merupakan toponim yang masih banyak didiami Cina Benteng atau menjadi kantong pemukiman Cina Benteng.

\section{PEMBAHASAN}

Pada sub-bab ini dipaparkan analisis yang dilakukan pada penelitian toponimi nama wilayah di Tangerang yang terkait dengan Cina Benteng sebagai berikut.

\section{a. Analisis Makna Leksikal}

\section{(1) Toponim karawaci}

Pada tingkatan leksikal tidak ditemukan kamus atau sumber yang memaparkan makna leksikal dari toponim Karawaci. Akan tetapi pada tingkatan etimologis Karawaci memiliki beberapa makna yang tidak bisa dilepaskan dari aspek Sejarah dan Budaya utamanya terkait Cina Benteng. Berdasarkan hasil wawancara dengan pelaku sejarah dan masyarakat Cina Benteng. Pertama Karawaci merupakan bentuk akronim dari Kara dan Kuaci. Kara berasal dari bahasa Indonesia, KBBI mendefinisikan Kara yaitu 'tumbuhan berbuah polongan, pohonnya merambat, buahnya sepanjang 5-7 cm, lebar dan berdaging tipis, kalau sudah tua berwarna hijau keputih-putihan'. Sedangkan, Kuaci menurut KBBI adalah 'biji semangka, bunga matahari, labu kuning, dan sebagainya yang dikeringkan dan diasinkan (untuk dimakan)'. Kara dan Kuaci merupakan camilan yang disuguhkan di meja ketika kita melayat di rumah duka etnis Cina. Berbeda dengan tradisi etnis Jawa atau Sunda yang tidak menyuguhkan apapun ketika berduka, etnis Cina akan menyuguhkan berbagai macam kacang dan kue (utamanya kacangkacangan) di meja tamu di rumah duka. Hal ini terjadi karena mayat tidak langsung dikebumikan, akan tetapi menunggu beberapa hari. Sehingga para pelayat datang silih berganti, duduk, dan bercengkerama di rumah duka sambil menyantap Kara dan Kuaci. Pendapat lain yaitu Karawaci merupakan akronim dari Kampung Arab Cina dan Jawa. Hal ini dikarenakan wilayah Karawaci dahulunya didiami ketiga etnis di atas di era penjajahan sebelum akhirnya Karawaci dikenal sebagai pemukiman Cina Benteng.

\section{(2) Toponim pasar lama}

Pada tingkatan leksikal, toponim pasar lama tentunya tidak dapat dirujuk secara utuh dalam KBBI. Akan tetapi apabila dipecah menjadi dua leksem yang berbeda yaitu pasar dan lama, maka dapat digali dalam KBBI yaitu pasar merupakan 'sebuah lokasi untuk berkumpul melakukan aktivitas jual dan beli', sedangkan lama merupakan kata sifat. Pada konteks toponim di Tangerang, berdasarkan penelusuran etimologi yang dibantu oleh informan setempat, 
penamaan Pasar Lama sudah semenjak jaman Belanda, Pasar Lama merupakan pasar paling tua di kota Tangerang dan memiliki fungsi ganda juga sebagai kawasan pecinan. Pasar Lama di masa lampau menjadi pusat perniagaan yang paling ramai. Tidak semata karena juga memenuhi fungsi sebagai pecinan tetapi keberadaan Pasar Lama yang di hulu sungai Cisadane, terdapat dermaga sehingga kapal-kapal kecil mengangkut komoditi dan melabuhkan kapalnya di sekitar Pasar Lama.

\section{(3) Toponim kampung melayu}

Berbeda dengan Pasar Lama yang terletak di Kota Tangerang, Kampung Melayu secara administratif terletak di Kabupaten Tangerang. Kampung Melayu, secara leksikal terdiri dari dua leksem yaitu kampung dan melayu. Kampung berdasarkan KBBI merupakan 'desa atau satuan wilayah administrasi terkecil dalam sebuah kecamatan'. Melayu mengacu pada suku bangsa yang berada di semenanjung Malaysia asia pada umumnya. Kampung melayu berdasarkan penuturan informan merupakan kampung yang penguasa atau raja di Tiga Raksa hadiahkan pada leluhur Cina benteng, Chen Chin Lung atau Alung. Ketika itu Kampung Melayu dijadikan pusat pemukiman untuk pendatang dari berbagai tempat dan ingin menetap di Tangerang dipersilakan menempati dan mengolah lahan di Kampung Melayu. Konsep melayu digunakan penduduk asli untuk mengacu penduduk pendatang atau asing.

\section{b. Analisis Makna Semiotik}

\section{(1) Toponim karawaci}

Toponim Karawaci merupakan sebuah simbol yang memiliki acuan dan memiliki konsep dalam tingkatan kognisi masyarakat Tangerang. Toponim Karawaci sebagai sebuah simbol dari referen yaitu wilayah administratif Karawaci yang merupakan bagian wilayah administratif Karawaci, Kota Tangerang. pada tingkatan konsep, Karawaci dipahami sebagai pemukiman yang banyak didiami etnis Cina, bila dibandingkan dengan daerah lain di Kota Tangerang. Pemaknaan pada tingkatan konsep atas toponim Karawaci oleh masyarakat Tangerang sudah tidak berada di tingkatan konotatif akan tetapi denotatif. Pemaknaan pada tingkatan konsep ini kemudian dapat dibantu dengan penjelasan lebih terperinci dalam analisis semiotik dan metabahasa sebagai berikut ini,

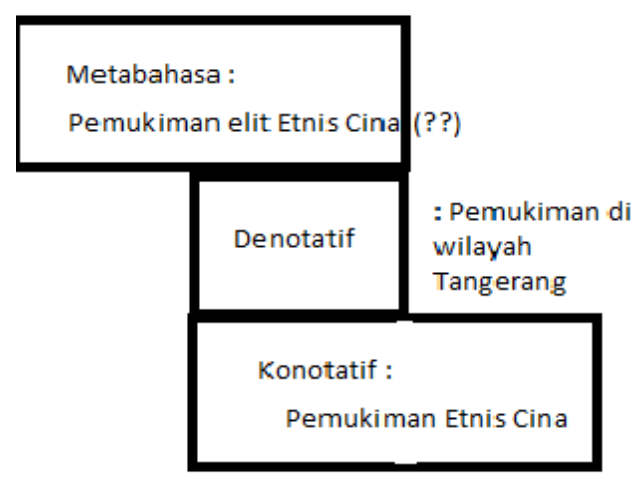

Gambar 8.2: Analisis Metabahasa dan Konotasi

Gambar di atas menggambarkan analisis metabahasa dan konotasi dari Toponim Karawaci. Pada tingkatan denotatif kata Karawaci dimaknai sebagai salah satu wilayah pemukiman di Kota Tangerang. Akan tetapi karena mayoritas yang tinggal di wilayah tersebut adalah etnis Cina Benteng, kemudian Karawaci dikenal sebagai pemukiman etnis Cina Benteng. Selanjutnya, pada tingkatan metabahasa, dewasa ini ketika orang Tangerang mendengar Karawaci yang ada dikonsep kognisi mereka bukan lagi pemukiman etnis Cina Benteng yang miskin akan tetapi pemukiman elit etnis Cina (bukan Benteng). Hal ini terjadi karena pada perkembangannya sebagian besar daerah Karawaci dikembangkan oleh Lippo 
Grup menjadi kota mandiri Lippo Karawaci. Sedangkan, etnis Cina Benteng masih mendiami Karawaci utamanya sepanjang jalan Karawaci Ilir (sekarang bernama Jalan Imam Bonjol). Etnis Cina benteng yang dulunya mendiami Lippo Karawaci sekarang tergeser ke daerah Curug. Akan tetapi, pemaknaan metabahasa di atas memerlukan lebih banyak informan untuk sehingga oleh penulis diberi tanda tanya di akhir kata.

\section{(2) Toponim pasar lama}

Pasar Lama merupakan terletak di tengah kota Tangerang, dewasa ini menjadi kawasan pecinaan yang terkenal akan kuliner jalanannya di malam hari. Mengacu pada makna leksikal pada makna leksikal, toponim Pasar Lama memenuhi makna denotatif sebagai sebuah lokasi digunakan untuk kegiatan jual beli. Selanjutnya, pada tingkatan konotasi, Pasar Lama ini diasosiasikan oleh masyarakat tangerang sebagai kawasan Pecinan, baik untuk berniaga maupun untuk bermukim. Hal ini sudah dikenal luas dari zaman lampau hingga sekarang. Kemudian seiring perkembangan sosial dan budaya di Tangerang, serta proses pembangunan yang dilakukan pemerintah, pergeseran pemaknaan terhadap Pasar Lama juga berpotensi terjadi. Berdasarkan hasil wawancara, masyarakat Pasar Lama dan sekitar, mengenal dan memaknai Pasar Lama sebagai kawasan Kuliner di Tangerang. Pemaknaan ini penulis asumsikan sebagai pemaknaan baru di tingkatan metabahasa. Program pemerintah kota Tangerang menjadikan kawasan Pecinan sebagai pusat wisata kuliner di Tangerang, mendapat tanggapan beragam dari masyarakat Pasar Lama sendiri. Sebagian memandang hal tersebut positif karena mampu menjadikan Pasar Lama bergairah di sore hingga malam hari. Akan tetapi tanggapan kurang positif juga mendominasi yaitu menganggap apa yang disuguhkan dan ada di dalam wisata kuliner tersebut tidak mencerminkan citra Pasar Lama yaitu sebagai kawasan Pecinan. Selain itu, masyarakat sekitar juga merasa perlunya pengelolaan limbah sampah yang baik serta melibatkan masyarakat Pasar Lama juga dalam pengelolaan Pasar Lama.

\section{(3) Toponim kampung melayu}

Toponim Kampung Melayu secara denotatif dipahami sebagai bagian atau kecamatan yang ada di wilayah administratif Kabupaten Tangerang. Letak kampung melayu berada di ujung utara Tangerang dan beberapa bagian wilayahnya berupa pesisir Pantai. Dahulu kala leluhur Cina Benteng mendarat pertama kali di pesisir pantai di Kampung melayu yaitu di Tanjung Pasir. Kemudian, dari masa ke masa kampung Melayu dikenal sebagai pusat pemukiman bagi Cina Benteng. Di wilayah tersebut banyak Cina Benteng memiliki lahan yang luas untuk bercocok tanam atau disewakan kepada pihak lain. Cerita ini menjadi dasar pertimbangan bahwa secara konotatif Kampung Melayu dimaknai sebagai pemukiman Cina Benteng meskipun pada dasarnya wilayah tersebut juga terdapat penduduk asli atau bahkan pendatang dari wilayah Jawa lain dan Sumatra. Selanjutnya, pada tingkatan metabahasa dewasa ini, berdasarkan penuturan informan kampung melayu dimaknai sebagai tempat cina benteng yang udik, atau dengan ekonomi yang masih cenderung menengah ke bawah yang hidup bertani. Pemikiran ini berkembang seiring dengan perkembangan pesat di wilayah-wilayah sekitar kabupaten dan kota Tangerang, banyak pemukiman mewah, pusat perbelanjaan, industri, dan bahkan kota mandiri. Seakan perkembangan ini tidak dapat diikuti oleh kampung melayu, sehingga cenderung generasi tua memilih tetap tinggal, sedangkan generasi muda memilih tinggal di tengah kota.

\section{c. Analisis Makna Toponim}

\section{(1) Toponim karawaci}

Pada tingkatan makna linguistik toponim Karawaci sudah diuraikan melalui makna etimologi dan makna semiotik. Selanjutnya, toponim karawaci memiliki makna dalam analisis 
toponimi yang dijelaskan dalam makna asosiatif, makna emotif, dan makna kategorial. Secara asosiatif, toponim Karawaci baik di zaman kuno dan sampai zaman orde baru diasosiasikan dengan etnis Cina Benteng, akan tetapi di era modern ini Karawaci diasosiasikan dengan etnis Cina elit (bukan Benteng). Hal ini memberi dampak pemberian makna emotif yang menuju ke arah yang lebih positif karena Karawaci tidak lagi dipahami sebagai pemukiman Cina miskin akan tetapi Cina elit yang modern. Selanjutnya, dari aspek kategori, pemaknaan terhadap toponim karawaci masuk dalam kategori sejarah. Menilik tiga jenis pemaknaan toponim Karawaci, berdasarkan hasil wawancara tatap muka, pemaknaan toponim Karawaci lebih didominasi oleh aspek kategorial yaitu aspek sejarah, sedangkan di era modern ini pemaknaan emotif lebih memegang peranan dalam pemaknaan oleh masyarakat sekitar.

\section{(2) Toponim pasar lama}

Selanjutnya, pada tingkatan analisis toponim, Pasar lama secara asosiatif dikaitkan dengan keberadaan Cina Benteng, meskipun dewasa ini suku bangsa dan budaya yang berdampingan hidup di Pasar Lama sangat beragam. Dari masa ke masa, sejarah mencatat masyarakat Tangerang cukup toleran dan mampu hidup berdampingan dengan berbagai budaya yang ada. Meskipun toponim Pasar Lama diasosiasikan sebagai pecinan, masyarakat dengan berbagai latar belakang dan tujuan berbeda tetap menjadikan Pasar Lama sebagai destinasi untuk dikunjungi atau berniaga disana. Hal ini menunjukkan secara asosiatif pemaknaan toponim Pasar Lama bergeser dari masa lampau ke masa sekarang.

\section{(3) Toponim kampung melayu}

Kampung Melayu pada cakupan pemaknaan leksikal dan semiotik menggambarkan adanya pergeseran dan perubahan makna. Pada tingkatan pemaknaan toponim, Kampung Melayu dimaknai secara emotif sebagai kampung milik orang pendatang di Tangerang. Pendatang tersebut di masa lampau mencakup Cina Benteng, India, dan Arab yang mendarat di Tangerang melalui jalur laut. Pada perkembangannya Kampung Melayu tidak hanya dihuni oleh Cina Benteng akan tetapi warga asli Tangerang juga cukup banyak mendiami kawasan tersebut. Berdasarkan hasil penelusuran dan wawancara, pemaknaan terhadap toponim Kampung Melayu di era modern ini lebih memenuhi aspek asosiatif, yaitu Kampung Melayu dikaitkan dengan Cina udik atau Cina benteng dengan status sosial menengah ke bawah. Penulis juga menemukan aspek emotif yaitu ketika banyak generasi muda merasa Kampung Melayu bukan lagi kampung halamannya, bagian dari diri pribadi, atau membuat sebagai olokan karena dianggap udik. Pergeseran pemaknaan dari emotif menuju asosiatif dan emotif ini menunjukkan perubahan pemaknaan yang terjadi pada masyarakat Cina benteng sendiri dan masyarakat sekitar.

\section{PENUTUP}

Berdasarkan tiga tahapan analisis di atas, data penelitian, yaitu toponim di kota Tangerang memiliki pemaknaan yang beragam dan juga mengalami perkembangan dalam pemaknaannya. Pada toponim Karawaci, Pasar Lama, dan Kampung Melayu tergambarkan bahwa analisis baik secara leksikal, semiotik, maupun makna toponim, makna yang muncul tidak dapat dilepaskan dengan konteks sosial, budaya, dan sejarah yang terkait dengan keberadaan Cina Benteng dari jaman dahulu hingga sekarang. Tahapan analisis di atas masih dilakukan dengan keterbatasan data, akan tetapi dapat digunakan sebagai gambaran kaitan analisis kebahasaan dapat menjadi pisau analisis isu sosial budaya yang ada dalam sebuah konteks bahasa. Pergeseran makna toponim merepresentasikan eksistensi Cina Benteng yang cenderung tergerus oleh arus perkembangan zaman dewasa ini. Makna toponim yang dijadikan contoh dalam pembahasan menggambarkan bahwa penelusuran makna toponim atau nama tempat dalam sebuah konteks budaya dapat menggambarkan eksistensi atau keberadaan sebuah etnis. Pada tulisan ini karena merupakan sebuah ancangan awal dan masih dalam proses 
analisis, belum tergambarkan secara utuh makna yang direpresentasikan oleh semua nama yang terkait Cina Benteng. Melalui penelitian ini dapat dipahami proses pelestarian budaya yang tercantum dalam kebijakan-kebijakan pemerintah atau instansi terkait seyogianya dilakukan dalam satu kesatuan aspek budaya. Kebijakan tentang penamaan tanpa disadari akan memengaruhi memori kolektif dan bahkan keberadaan sebuah etnis.

\section{DAFTAR PUSTAKA}

Ayatrohaedi. (1993). Kata, Nama dan Makna. dalam Pidato Pengukuhan Guru Besar, Fakultas Ilmu Pengetahuan Budaya, Universitas Indonesia.

Budiasih, Liny. 2015. Variasi Bahasa Masyarakat Cina Benteng Di Wilayah Tangerang: Sebuah Kajian Dialektologi. Skripsi Program Studi Bahasa Indonesia, Fakultas Ilmu Pengetahuan Budaya, Universitas Indonesia.

Daradjadi. 2017. Geger Pecinan 1740 - 1743. Persekutuan Tionghoa - Jawa Melawan VOC. Jakarta: Kompas.

Gobard, H. 1976. L" aléniation Linguistique. Paris: Flamation.

Hall, Stuart.1990. Cultural Identity and Diaspora. London: Lawrence and Wishart.

Hough, C. 2016. Introduction. In C. Hough, The Oxford Handbook of Names and Naming (pp. 1-16). Oxford: Oxford University Press. https://doi.org/10.1093/oxfordhb/9780199656431.001.0001

Koentjaraningrat. 1997. Masyarakat dan Kebudayaan Indonesia. Jakarta: Djambatan.

Muhatta, Zarmahenia. 2019. Kajian Toponimi Terhadap Bandar-bandar di Jalur Rempah Pantai Utara Pulau Jawa Pada Abad ke-15 sampai ke-19. Disertasi Program Studi Ilmu Linguistik, Fakultas Ilmu Pengetahuan dan Budaya, Universitas Indonesia.

Lauder, RMT. 1990. Pemetaan dan Distribusi Bahasa di Tangerang. Disertasi, Departemen Linguistik, Fakultas Ilmu Pengetahuan Budaya.

Lusiana, Theresia Mereisye. 2013. Penyebaran Agama Katolik pada Masyarakat Cina Benteng di Kota Tangerang tahun 1952 - 1985. Skripsi, Program Studi Ilmu Sejarah, Fakultas Ilmu Pengetahuan Budaya, Universitas Indonesia.

Nyström, S. 2016. Names and Naming. In C. Hough, The Oxford Handbook of Namesand Naming (pp. 39-51). Oxford: Oxford: Oxford University Press. https://doi.org/10.1093/oxfordhb19780199656431.013.26

Perdana, Purnama Rika. 2019. Dinamika Nama Marga Etnik Simalungun: Kajian Antroponimi. Disertasi Program Studi Ilmu Linguistik, Fakultas Ilmu Pengetahuan dan Budaya, Universitas Indonesia

Priscylia, Regina. 2015. Upacara Makan 'Dua Belas Mangkok' dalam upacara Pernikahan Peranakan Tionghoa di Tangerang (Cina Benteng). Makalah non seminar Program Studi Cina, Fakultas Ilmu Pengetahuan Budaya, Universitas Indonesia.

Ramadhanty, Triaputri Suci. 2016. Upacara Pernikahan Tradisional Masyarakat Cina Benteng di Tangerang: Sawer dan Pendaringan. Makalah nonSeminar, Program Studi Cina, Fakultas Ilmu Pengetahuan Budaya, Universitas Indonesia.

Sany, Yudhanty Parama. 2013. Kewarganegaraan di Indonesia: Studi Kasus Kontestasi Konstruksi Identitas Etnis Cina Benteng. Tesis, Program Studi Pasca Sarjana Ilmu Politik, Fakultas Ilmu Sosial dan Politik, Universitas Indonesia.

Thresnawaty, Euis. (2015). Sejarah Sosial Budaya Masyarakat Cina Benteng Di Kota Tangerang. Jurnal Patanjala, 7(1). https://doi.org/10.30959/patanjala.v7i1.83

Triyanda, Nola. 2016. Ritual Berkabung dalam Upacara Kematian Masyarakat Peranakan Cina Benteng. Makalah non seminar, program studi Cina, Fakultas Ilmu Pengetahuan Budaya.

Wiyono, Radjimo Sastro. 2013. Wayang Cokek: Tradisi Lisan dan Pengelolaannya Pada Masyarakat Cina Benteng, Tangerang. Tesis, Departemen Susastra, Fakultas Ilmu Pengetahuan Budaya, Universitas Indonesia.

Zaini, Muhammad Reza. 2014. Perjalanan Menjadi Cina Benteng. Jurnal Sosiologi Masyarakat, 19(1). https://doi.org/10.7454/mjs.v19i1.4698 